\title{
The Construction and Development of Open Network Learning Platform in Higher Vocational Education
}

\author{
Yiqiang Liao \\ School of Continuing Education \\ Guangdong Industry Technical College \\ Guangzhou, China 51300
}

\begin{abstract}
Facing the society to carry out continuing education of enterprise employees is an important function of higher vocational colleges. Under new technology trend, with the help of network methods, implementing remote online education has provided vast development prospect for continuing education of higher vocational education. It is necessary to exploit the advantages of higher vocational colleges and network education to the full, use scientific development perspective as the guidance, aim at various problems exposed by present network learning and platform construction to put forward construction thinking on open network learning platform of continuing education that meets the requirements of enterprises and society.
\end{abstract}

Keywords - higher vocational education; online education; network learning

\section{NETWORK IS AN INEVITABLE CHOICE FOR TEACHING REFORM AND APPROACH EXPLORING OF CONTINUING EDUCATION OF HIGHER VOCATIONAL COLLEGES}

As the main way of cultivating high quality skill-oriented talents in our country, higher vocational education is an important part of national educational system and human resource development and shoulders important responsibilities to cultivate diversified talents, inherit technical skills and promote employment and entrepreneurship. On June 23, 2014, Xi Jinping, the general secretary, clearly points out in "the vital instructions on vocational education" that: create the good environment that everyone can become an useful person and show talents heartily; make efforts to cultivate hundreds of millions of high quality workers and technical and skilled talents. We should firmly grasp the orientation of education of service development and employment promotion, deepen institutional mechanism reform, renovate the pattern of higher vocational education at all levels, insist the fusion of production and education and the cooperation between school and enterprise, the combination of learning with working and the unity of knowing and doing, guide all sectors of the society especially industry and enterprises to positively support education and endeavor to construct the vocational education system with Chinese characteristics. At present, there are more than 12,000 secondary vocational schools and over 1,300 higher vocational schools throughout the country. The total scale in the year of enrollment is 10,000,000. There are almost 30,000,000 students at school. Each year, we have trained all kinds of personnel for 150 million times. And we have constructed the largest scale of vocational educational system in the world.

The Third Plenary Session of 18th CPC Central Committee clearly puts forward that "to build a lifelong vocational training system for workers". Practice has proved that only by relying on vocational colleges, developing vocational education and carrying out vocational training on a large scale can we realize the gradual construction of vocational training system that runs through all stages from learning to working of laborers and adapts to the demands of diversification and differentiation of workers. Constructing first-class higher vocational colleges is an important content to build lifelong vocational training system for workers, which must be based on the actual requirements of regional economic development and lifelong career development of students to cultivate high-level practical talents of technology application, technical management and social services. At present, informatization gradually holds dominant position in people's lives and internet sets up learning platform for us. As the educational reform hotspot of higher education in our country in recent years, the combination of higher vocational education and network learning will inevitably bring new reform and the qualitative leap for the development of higher vocational education. The construction of network learning platform is the core content and foundation of realization of remote education system and the key to successfully implement and carry out teaching activities of remote continuing education. Network learning platform has become an effective path for higher vocational colleges to provide extensive and fair learning opportunities for enterprise employees and enhance the qualities of individuals, organizations and even the whole society. Through organizing network learning and online training, inner-enterprise can improve skills and qualities of employees and develop towards learning team and learning organization. Network learning platform is an online platform to provide a variety of courses for user to learn and record the learning process. As the main teaching object, 
workers at the production line in the enterprises have become the main beneficiaries in this development. As a new study method, different from face to face teaching such as traditional amateur learning and distance learning and the form of answering questions face to face intensively, it uses modern information technology means such as internet and digital multimedia technology to coordinate and organize all kinds of media information such as data, voice and images together to vividly impart knowledge and information. Open network learning presents the open, equal, virtual and autonomous characteristics.

\section{PROBLEMS EXISTING AND EXPOSED OF TEACHING AND LEARNING OF OPEN NETWORK PLATFORM IN PRESENT CONTINUING EDUCATION}

The main functions of network learning platform include using modern technological means and rich instructional resources to provide good autonomous learning environment for students, providing support for the whole process of teaching links such as teaching, learning, exchanges, assignments and examination through on-line management. Therefore, network learning platform should have the functions such as support teachers to teach online and answer questions, support course learning of students, submitting assignments online, asking questions, discussion, examination and teaching management, and comprehensive functions such as assign, give out and correct homework, analyze testing scores, manage achievements of students and course management, etc. Compared with traditional school education, quite a few teaching objects in network education are adults, namely employed workers at the production line in enterprises. They expect the knowledge learned by them has close relationships with their professional posts. Under great pressures of responsibilities in working, school, family and society, it is difficult to guarantee their learning time and they lack good learning environment. Once making educational input, they expect to get higher returns in life and working.

In teaching process of open network platform of continuing education, teacher factors cannot be ignored. Existing problems at the present stage mainly focus on: teachers lack teaching experience of network learning. Previous accumulation of traditional classroom teaching experience is not suitable for network environment to a large extent. Teachers cannot completely adapt themselves to keeping away from lectures and changing from traditional classroom teaching that regards teaching plan as essentials to the control of focusing on the teaching process. The development and support of platform excessively and objectively emphasize technologies such as distribution of course content and online examination, cannot start from the perspectives of learners and meet the requirements of objective education, lack methods and skills to expand teaching interaction and timely feedback and solutions of opinions and problems of learners.

The use of network learning platform requires learners to master relevant technology. It is essential to simplify the dependence of network learning for technology and software to the greatest extent. Extra requirements for hardware and software not only increase learning cost, but also occupy limited learning time and resources. Complex network learning environment and the lack of necessary technical support affect the ease of use of network education system and then reduce applicability and rationality. Practice shows that the proficiency of learners to operate network learning platform is in direct proportion to learning initiative and learning effect.

\section{DEVELOPMENT IDEAS OF OPEN NETWORK LEARNING PLATFORM OF CONTINUING EDUCATION}

\section{A. Student-centered Idea Should be Established in Various Links of the Construction.}

Establishing student-centered idea is not only the core connotation of the educational concept of open learning, but also the central content of modern education theory and learning theory. Network educational teaching requires teachers and educational institutions to change their role and become student-centered. These are fully reflected on network teaching platform and the exploitation and transmission of course design, and the support services of students' learning in the whole teaching process. As a new kind of means of education, it provides students with rich learning resources and multiple choices of learning time. Students dominate learning process and actively construct knowledge instead of passive acceptance and infusion. Starting from the perspective of students, compared with traditional education, network education is more open, selective, diversified, adaptable and flexible.

\section{B. Reasonably Establish Management Organization of Modern Remote Education in Colleges.}

Establish special agency inside the school to manage network teaching, bring the exploitation and development into the central internship and practical training of reform and development of school education, and fully realize the importance of network educational teaching from top to bottom. Strictly implement education policies and regulations of national departments concerned, standardize teaching work, strengthen the management in the process of network educational teaching, establish the "Quality First" management philosophy of the network educational teaching process, set up scientific method of network educational teaching process, and use advanced technological means to strengthen the quality control management of the whole teaching process.

\section{Strengthen the Management of Learning Support Services.}

Focus on the teaching quality and put the construction of high-quality course resources and providing high-quality education services in the first place; speed up the construction pace of course resources and learning resources, and integrate industry and enterprise to fully mobilize social resources and choose reasonable operating model of resource construction. As an open system, network learning platform should consider in the long run on design and planning. First of all, it should meet the increasingly urgent requirements of 
continuing education of the present society and enterprises. Meanwhile, it should see from the construction of learning society under the new situation of economic development and meet the demands of learning promotion and system support services in the next period of time. Open the learning contents, forms, means and the interaction of teaching, information feedback in space and time, and build the flyover among different forms of education such as degree education (college degree, bachelor degree and master degree) and non-degree education (trainings of skills and certificate), etc.

\section{Connect Industry and Enterprises to Strengthen the construction of Off-Campus Learning Center.}

Closely combine industry and enterprises with professional advantages of schools and advantages of location technology radiation, timely grasp the frontier development of industry technology, positively help enterprises to implement the continuing education of employees and the secondary development of human resources, realize individualistic learning of continuing education for enterprise employees, and replace control with interaction and make lifelong learning system of vocational education. Establish sites according to law, reasonably construct network system of remote education, strengthen team construction of teaching management and learning support services, strengthen the construction of teaching infrastructures, help enterprises to timely update software and hardware facilities. Condition permitting, enterprises can set up special teaching place. Schools should load separation and give technical support and assistance.

\section{E. Set up Service Awareness.}

In face of the construction of network learning platform of continuing education in enterprises, we should adhere to "Service First". People from top to bottom must take correct service concept as the guiding ideology, grasp the constitutive relations between continuing education work and individual overall development of enterprise employees, and always place service for students and strict control and improvement of teaching quality at the core position of the construction of network education platform, and closely centre on core work of placing teaching quality first to provide services. Combine the current technical standard of enterprises, development tendency of continuing education for employees and the objectives of learning of whole people and lifelong education, and integrate education teaching resources and learning links such as degree and non-degree education (skill training), technique popularization and application and assessment of skills and certificates. In addition, we should make them integrate into the network learning platform of continuing education, utilize the integration effect of learning platform to provide enterprise employees with comprehensive service of continuing education.

\section{CONCLUSION}

At present, the recognition degree of network education is unprecedented. Network learning environment of higher vocational education has been preliminarily formed and has guided the widespread application of advanced technology in high vocational colleges to some extent, thus promoted comprehensive improvement and reform of higher vocational education, management of continuing learning as well as operation mechanism. In the construction work of network learning platform of continuing education, higher vocational colleges should fully reflect the teaching characteristics that remote education uses the cultivation of students' autonomous learning ability to run through the whole process of education, and combines teaching model of comprehensive application of various teaching media and counseling methods. Through network learning platform, gather the integration and teaching application function of all kinds of teaching resources, fully consider the convenience of use for teaching managers, teachers and students, and the individualized requirements of network online learning, and provide a good network online supported environment of teaching and learning. It is feasible to improve the level of teaching management, enhance teaching quality and work efficiency, help teaching objects of continuing education to actively and efficiently learn independently. Besides, we should make this new type of education integrate with vocational education, meet the vocational and technical requirements at the present stage to serve for social and economic development and the construction of lifelong vocational training system of laborers

\section{REFERENCES}

[1] Ministry of Education. Vital Instructions of General Secretary Xi Jinping on Vocational Education, 2014

[2] Wang Cong, Li Min, Chu Jianjie. Application Countermeasures of Construction Model of Network Teaching Platform in Information Construction in Colleges [J], China Education Info, 2010(11)

[3] Wu Hanmei, Huang Daohua. Discussion on the Construction of Network Learning Platform of Modern Remote Education [J], Education and Vocation, 2008(27)

[4] Chu Guanpeng. Research on Influence Factor of Application Efficiency and Promotion Strategy of Network Teaching Platform [D], Guangzhou University, 2012 